\title{
Pemanfaatan Limbah Kulit Buah dan Sayur Sebagai Bahan Bakar Bioetanol dengan Variasi Konsentrasi Katalis
}

\section{Utilization of Fruit Peels and Vegetable Waste as Bioethanol Fuel with Variation of Catalyst Concentration}

\author{
Eva Agustina*, Gita Ika Safitri, Irssa Intan Fatiha, Muhammad Iqbal Pratama, Rahmania, Ria Safitri, \\ Funsu Andiarna, Irul Hidayati \\ Program Studi Biologi, Fakultas Sains dan Teknologi, Universitas Islam Negeri Sunan Ampel Surabaya, \\ Jl. Ahmad Yani 117, Surabaya, 60237, Indonesia \\ *Email: eva_agustina@uinsby.ac.id
}

\begin{abstract}
Abstrak
Bahan bakar fosil termasuk dalam sumber energi tidak terbarukan, sehingga keberadaannya di Indonesia semakin berkurang. Salah satu sumber energi terbarukan yang dapat diperoleh dengan mudah adalah bioethanol. Bioetanol berasal dari bahan organik yang mengandung serat selulosa melalui tahapan hidrolisis dengan katalis dan fermentasi. Tujuan penelitian ini yaitu untuk mengetahui pengaruh variasi konsentrasi katalis dalam pembuatan bioetanol dari limbah organik pasar (kulit buah dan sayuran). Ada tiga tahap mengubah limbah organik menjadi bioetanol, tahap pertama adalah mengubah limbah sayuran hijau dan kulit buah yang mengandung polisakarida atau selulosa menjadi monosakarida (gula sederhana) dengan proses hidrolisis diikuti dengan proses fermentasi menggunakan Saccharomyces cerevisiae dan EM4, kemudian pemisahan etanol dan air menggunakan proses distilasi. Produk yang dihasilkan dianalisis menggunakan tes kuantitatif untuk menentukan densitas dan tes kualitatif untuk menentukan perubahan warna. Hasilnya menunjukkan bahwa etanol yang diperoleh dari penambahan katalis $\mathrm{H}_{2} \mathrm{SO}_{4}$ dengan konsentrasi $0,5 \%$ dan $1 \%$ memiliki spesifikasi yang hampir sama dengan etanol standar berdasarkan perhitungan densitas dan uji perubahan warna. Hasil etanol yang diperoleh atau \% yield terbanyak diperoleh dari konsentrasi $\mathrm{H}_{2} \mathrm{SO}_{4} 1 \%$.
\end{abstract}

Kata kunci : limbah organik, hidrolisis, fermentasi, distilasi, bioetanol

\begin{abstract}
Fossil fuels are included as non-renewable energy sources, so its presence in Indonesia is decreasing. One of the renewable energy sources that can be obtained easily is bioethanol, this energy is obtained from organic materials containing cellulose fibers. Cellulose is hydrolyzed on a catalyst and fermented to obtain bioethanol. The aim of this study was to determine the effect of variations in the concentration of catalysts in the production of bioethanol from market organic waste (fruit peels and vegetables). There are three stages of converting organic waste into bioethanol, including converting green vegetables waste and fruit peels (polysaccharides / cellulose) into monosaccharides (simple sugars) through a hydrolysis process followed by a fermentation process using Saccharomyces cerevisiae and EM4, then separating ethanol and water using a distillation process. The resulting products are analyzed using a quantitative test to determine density and a qualitative test to determine color change. The results showed that the ethanol obtained from the addition of $\mathrm{H}_{2} \mathrm{SO}_{4}$ catalyst with concentrations of $0.5 \%$ and $1 \%$ had almost the same specifications as standard ethanol based on density calculations and color change tests. The highest ethanol yield percentage was obtained from the concentration of $\mathrm{H}_{2} \mathrm{SO}_{4} 1 \%$.
\end{abstract}

Keywords: organic waste, hydrolysis, fermentation, distillation, bioethanol

\section{Pendahuluan}

Berkurangnya ketersediaan bahan bakar fosil merupakan masalah yang terjadi dari tahun ke tahun. Berdasarkan data dari Administrasi Umum Migas pada tahun 2016 menyebutkan bahwa dalam setiap tahunnya, kandungan minyak bumi terus menipis serta terus mengalami penurunan. Penurunan jumlah produksi bahan bakar fosil sekitar 25,3\% dari tahun 2015 ke 2016 [1]. Meningkatnya kebutuhan manusia dan pesatnya perkembangan transportasi saat ini 
menjadi pemicu kekurangan bahan bakar. Kandungan minyak bumi yang terus mengalami pengurangan menjadikan masyarakat berinovasi dalam mencari sumber alternatif pengganti bahan bakar fosil. Bahan bakar yang saat ini dinilai lebih ramah lingkungan dan merupakan salah satu bahan bakar terbarukan yaitu bioetanol $\left(\mathrm{C}_{2} \mathrm{H}_{5} \mathrm{OH}\right)$ [2].

Penggunaan bioetanol sebagai bahan bakar dapat mengurangi emisi karbon dioksida sebanyak $18 \%$. Bioetanol berasal dari penggunaan bahan organik serat kasar dengan kandungan karbohidrat tinggi yang diuraikan dan diolah menjadi bioetanol. Proses perombakan bahan organik menjadi etanol melalui tahapan hidrolisis, fermentasi dan distilasi. Proses hidrolisis bertujuan untuk memecah karbohidrat kompleks menjadi struktur yang lebih sederhana, sedangkan proses fermentasi bertujuan untuk mendapatkan alkohol atau etanol dengan bantuan mikroba Saccharomyces cerevisiae yang diperoleh dari ragi. Alkohol yang diperoleh dari proses fermentasi dimurnikan dengan teknik distilasi [3].

Karbohidrat yang mengandung selulosa merupakan komponen bahan baku bioetanol. Limbah organik dari pasar tradisional dapat dijadikan sebagai bahan baku pembuatan bioetanol karena banyak mengandung selulosa. Limbah organik yang tidak termanfaatkan dengan baik dapat menimbulkan dampak permasalahan lingkungan seperti timbulnya bau tidak sedap, kotor dan kumuh. Untuk mengatasi permasalahan tersebut, dalam penelitian ini digunakan limbah organik yang berasal dari pasar tradisional seperti kulit buah dan sayur yang tidak layak konsumsi sebagai bahan baku pembuatan bioetanol. Kulit buah dan sayur memiliki kandungan selulosa tinggi sehingga dapat digunakan sebagai bahan baku bioetanol. Karbohidrat yang terkandung dalam limbah organik sebanyak $60 \%$, dan komponen selulosa dalam karbohidrat tersebut digunakan dalam proses fermentasi untuk menghasilkan bioetanol [4].

Pada umumnya proses produksi bioetanol memerlukan katalis atau senyawa yang mampu mempercepat laju reaksi untuk mencapai titik kesetimbangan dalam reaksi kimia dan tidak mempengaruhi hasil reaksi. Menurut penelitian terdahulu, katalis yang digunakan meliputi asam klorida $(\mathrm{HCl})$, amonium hidroksida $\left(\mathrm{NH}_{4} \mathrm{OH}\right)$ dan asam sulfat $\left(\mathrm{H}_{2} \mathrm{SO}_{4}\right)$ dalam bentuk cair atau pekat [5]. Katalis berpengaruh pada proses hidrolisis dan fermentasi, dalam pembentukan monosakarida melalui penguraian selulosa dan hemiselulosa. Asam sulfat berbentuk cairan, mudah menguap dan tidak berwarna. Salah satu katalis yang dapat digunakan adalah asam kuat dengan konsentrasi encer [6].

Penelitian yang dilakukan oleh Miskah dkk memaparkan bahwa penggunaan katalis asam encer memiliki perbedaaan dengan katalis asam pekat dalam proses hidrolisis dan fermentasinya. Penggunaan asam kuat encer memudahkan dalam penghilangan asam dari hasil reaksinya. Selain itu, penggunaan katalis asam kuat dengan konsentrasi pekat akan diperoleh glukosa tinggi dan mencapai kadar yang optimal. Selain itu, pada proses hidrolisis dan fermentasi penggunaan asam kuat pekat menghasilkan endapan kapur. Namun, keluaran limbah kapur yang dihasilkan oleh asam encer jauh lebih kecil. Kadar etanol hasil distilasi diuji dengan metode kuantitatif dengan melihat berat jenis atau densitasnya dan kualitatif dengan melihat perubahan warna [7]. Tujuan dalam penelitian ini yaitu untuk mengetahui adanya pengaruh variasi konsentrasi katalis asam sulfat $(0,5 \%, 1 \%$ dan $5 \%)$ dalam pembentukan bioetanol yang berasal dari limbah organik pasar (kulit buah dan sayur).

\section{Teori}

Bioetanol adalah salah satu jenis etanol yang berasal dari sumber biologis etanol yang mengandung pati, gula dan serat selulosa. Faktor yang berengaruh terhadap pembentukan etanol antara lain adalah penentuan sel ragi, konsentrasi asam, kadar gula, suhu dan oksigen [7]. Wusnah dkk telah melakukan beberapa penelitian dengan menggunakan beberapa bahan baku yang mengandung karbohidrat untuk menghasilkan bahan bakar bioetanol, termasuk kulit pisang kepok. Dalam pembuatan biodisel kulit pisang kepok yang mengandung karbohidrat akan diubah menjadi glukosa dan selanjutnya menjadi etanol. Proses hidrolisis kulit pisang kepok dengan menambahkan katalis $\mathrm{HCl} 5 \%$ pada suhu $80{ }^{\circ} \mathrm{C}$ selama 60 menit, kemudian difermentasi selama 7 hari dengan bantuan ragi Saccharomyces cerevisiae. Filtrat hasil dari proses fermentasi didistilasi pada suhu $80{ }^{\circ} \mathrm{C}$ untuk memisahkan etanol dengan zat pencampur lainnya, sehingga diperoleh etanol murni [4].

Penelitian yang dilakukan Asteria pada tahun 2013 menunjukkan bahwa kulit pisang kepok mengandung karbohidrat, kalsium dan vitamin C. Pisang kepok dihaluskan terlebih dahulu, kemudian dihidrolisis dalam larutan $\mathrm{HCl}$ dengan variasi suhu $50^{\circ} \mathrm{C}, 60^{\circ} \mathrm{C}, 70^{\circ} \mathrm{C}$ dan $80^{\circ} \mathrm{C}$ selama 1 jam. Proses fermentasi menggunakan jamur, variabel nutrien diammonium hidrogen fosfat $\left(\mathrm{NH}_{4}\right)_{2} \mathrm{HPO}_{4}(10,20$ dan $30 \mathrm{~g} / \mathrm{L})$ selama 12 hari. Rendemen glukosa terbanyak diperoleh dari proses hidrolisis pada suhu $70{ }^{\circ} \mathrm{C}$ selama 1 jam sebesar 83,021 g/L. Hasil fermentasi pada hari ke 8 diperoleh 314,46 gram etanol [8].

Purba menyebutkan dalam penelitiannya bahwa kulit kentang mengandung karbohidrat. Pada proses ini kulit kentang yang sudah halus dihidrolisis dengan $\mathrm{H}_{2} \mathrm{SO}_{4}$ selama 1 jam pada suhu $100{ }^{\circ} \mathrm{C}$. Hasil hidrolisis ditambahkan larutan $\mathrm{NH}_{4} \mathrm{OH}$ samapai $\mathrm{pH} 5$ proses ini disebut detoksifikasi. Tahap selanjutnya adalah fermentasi dengan Saccharomyces cerevisiae selama 7 hari. Hasil fermentasi kemudian didistilasi pada suhu sekitar $78-84{ }^{\circ} \mathrm{C}$. Etanol yang diperoleh dari 5 g kentang kering adalah 15,85\% [6].

Penelitian Seftian, menyatakan bahwa kulit pisang mengandung senyawa lignoselulosa yang 
cukup tinggi dan diubah menjadi glukosa yang dapat digunakan sebagai bahan baku pembuatan bioetanol. Lignoselulosa yang ada pada kulit pisang dihilangkan dengan asam kuat $\mathrm{H}_{2} \mathrm{SO}_{4}$ encer $1 \%$ dan $\mathrm{NaOH} 4 \%$ terjadi pada proses hidrolisis. Setelah itu dilakukan fermentasi dengan Saccharomyces cerevisiae. Produk fermentasi dipisahkan dari residu kemudian didistilasi untuk memisahkan etanol dari campurannya. Pada fermentasi ke-5 produk akhir yang diperoleh dengan menggunakan enzim $9 \mathrm{~mL}$ sebesar 13,1154\% [3].

Kurniawan memaparkan dalam penelitiannya bahwa jerami mengandung 39\% selulosa dan $27,5 \%$ hemiselulosa. Selulosa dan hemiselulosa dapat dibuat menjadi bioetanol dengan menghidrolisisnya menjadi gula sederhana. Proses fermentasi dilakukan selama 14 hari dengan menambahkan Saccharomyces cereviseae [2]. Sel khamir dengan $\mathrm{pH}$ optimal 4,0-4,5 digunakan sebagai media produksi alkohol dari limbah organik selulosa. Aktivitas Saccharomyces cerevisiae dalam proses hidrolisis dan fermentasi dapat menghasilkan etanol yang baik [9]. Hasil fermentasi kemudian didistilasi pada suhu $80{ }^{\circ} \mathrm{C}$ untuk memisahkan air dan etanol. Etanol yang diperoleh dengan kadar 95\%. Kadar etanol > 99,5\% v/v atau disebut dengan fuel grade ethanol (FGE) dan digunakan untuk bahan bakar kendaraan bermotor [2].

\section{Metodologi Penelitian}

Alat

Alat yang digunakan dalam penelitian ini adalah gelas ukur, pipet, blender, neraca, mortar, pipet tetes, wadah, pengaduk, spatula, gelas beker, botol kuljar, timbangan analitik, termometer, labu ukur, penjepit, kompor elektrik, statif dan alat distilasi.

\section{Bahan}

Bahan yang digunakan meliputi limbah organik pasar yaitu limbah sayuran dan kulit buah yang sudah dibuang dan tidak layak konsumsi, cairan EM4, ragi Saccaromyces cerevisiae, aquadest, larutan kalium dikromat $\left(\mathrm{K}_{2} \mathrm{Cr}_{2} \mathrm{O}_{7}\right)$ dan larutan asam sulfat $\left(\mathrm{H}_{2} \mathrm{SO}_{4}\right)$

\section{Prosedur Kerja}

\section{Penyiapan Bahan Utama}

Kulit buah dan sayuran dari limbah organik pasar dipotong kecil-kecil dan dicuci dengan air mengalir. Sebanyak 1,5 Kg limbah kulit buah dan sayuran dihaluskan dengan blender sampai menjadi bubur. Limbah organik yang sudah halus dan menjadi bubur kemudian disaring, dan dibagi ke dalam tiga wadah.

\section{Proses Hidrolisis dan Fermentasi}

Hasil penyaringan sari limbah organik dimasukkan ke dalam wadah dan ditambahkan EM4 sebanyak $1 \mathrm{~mL}$ pada setiap masing-masing wadah. Larutan $\mathrm{H}_{2} \mathrm{SO}_{4}$ dengan konsentrasi $0,5 \%$ dimasukkan ke dalam wadah 1; larutan $\mathrm{H}_{2} \mathrm{SO}_{4} 1 \%$ ke dalam wadah 2 dan larutan $\mathrm{H}_{2} \mathrm{SO}_{4} 5 \%$ ke dalam wadah 3. Tahap selanjutnya 1 gram ragi yang dilarutkan dalam $100 \mathrm{~mL}$ aquadest ditambahkan ke setiap wadah. Wadah ditutup untuk mengurangi penguapan $\mathrm{H}_{2} \mathrm{SO}_{4}$. Proses fermentasi ditunggu selama 9 hari untuk mendapatkan etanol dan air.

\section{Proses Distilasi (Pemurnian Etanol)}

Langkah selanjutnya adalah memasang unit distilasi yang terdiri dari alat pemanasan, labu tempat sampel, termometer, kondensor dan wadah tempat keluarnya etanol. Langkah pertama yang dilakukan adalah memasukkan cairan hasil fermentasi ke dalam labu distilasi. Temperatur pemanas harus dijaga pada $78{ }^{\circ} \mathrm{C}$ sampai cairan etanol menetes perlahan kedalam wadah penampungan, proses tersebut terjadi kurang lebih selama 12 jam.

\section{Uji Etanol}

Uji etanol dengan mengamati perubahan warna dan penghitungan densitas. Pengamatan perubahan warna dengan cara meneteskan larutan $\mathrm{K}_{2} \mathrm{Cr}_{2} \mathrm{O}_{7}$ yang berwarna jingga dalam kondisi asam tetes demi tetes ke dalam etanol yang dihasilkan dari variasi konsentrasi $\mathrm{H}_{2} \mathrm{SO}_{4} \quad 0,5 \%, 1 \%$ dan $5 \%$. Jika warna larutan berubah dari jingga menjadi hijau kebiruan maka etanol yang dihasilkan akan bernilai positif [10]. Perhitungan densitas etanol dilakukan dengan menggunakan persamaan (1).

$$
\rho=\frac{m}{v} g / m L
$$

dimana $\mathrm{m}$ adalah massa yang dihasilkan, $\mathrm{v}$ adalah volume yang dihasilkan, dan $\rho$ adalah lambang densitas [11].

\section{Hasil}

Tahap awal proses produksi bioetanol adalah reaksi hidrolisis. Prinsipnya adalah menguraikan kandungan polisakarida atau karbohidrat dalam bentuk selulosa dan hemiselulosa pada limbah organik menjadi monosakarida dan $\mathrm{H}_{2} \mathrm{O}$. Menurut penelitian yang dilakukan oleh Seftian dkk bahwa hidrolisis selulosa menghasilkan monosakarida atau glukosa, sedangkan hemiselulosa berubah menjadi pentosa $\left(\mathrm{C}_{5}\right)$ dan heksosa $\left(\mathrm{C}_{6}\right)$ [3]. Dalam penelitian ini, proses hidrolisis limbah organik menggunakan asam sulfat $\left(\mathrm{H}_{2} \mathrm{SO}_{4}\right)$ dengan variasi konsentrasi $0,5 \%, 1 \%$ dan $5 \%$. Proses hidrolisis ditunjukkan pada persamaan reaksi berikut:

$$
\left(\mathrm{C}_{6} \mathrm{H}_{10} \mathrm{O}_{5}\right) \mathrm{n}+\mathrm{nH}_{2} \mathrm{O} \underset{\mathrm{H}_{2} \mathrm{SO}_{4}}{\longrightarrow} \mathrm{nC}_{6} \mathrm{H}_{12} \mathrm{O}_{6}
$$

Asam sulfat atau $\mathrm{H}_{2} \mathrm{SO}_{4}$ dipilih karena $\mathrm{H}_{2} \mathrm{SO}_{4}$ merupakan senyawa asam kuat. Asam kuat lebih reaktif terhadap penguraian lapisan lignin dalam selulosa dibandingkan asam lemah, dan lebih mudah 
larut. Kadar lignin yang tinggi perlu diturunkan untuk mengatur reaktivitas selulosa selama proses hidrolisis, sehingga meningkatkan kadar glukosa yang akan diproduksi [12].

Proses fermentasi dalam penelitian ini menggunakan ragi Saccharomyces cerevisiae dan cairan EM4 (Effective Microorganisme) yang dapat digunakan untuk mengubah glukosa menjadi etanol dan gas $\mathrm{CO}_{2}$. Reaksi fermentasi glukosa menjadi alkohol dapat dilihat dari ersamaan reaksi berikut:

$$
\mathrm{C}_{6} \mathrm{H}_{12} \mathrm{O}_{6} \longrightarrow 2 \mathrm{C}_{5} \mathrm{H}_{5} \mathrm{OH}+2 \mathrm{CO}_{2}
$$

Bakteri Saccharomyces cerevisiae merupakan mikroorganisme bersel tunggal yang digunakan dalam proses fermentasi. Penggunaan khamir yang mengandung Saccharomyces cerevisiae dan EM4 dapat meningkatkan efisiensi pembuatan bioetanol. Etanol yang dihasilkan dari proses fermentasi menghasilkan alkohol yang tidak beracun, memiliki bau yang khas dan tidak berwarna. Bioetanol ini dapat digunakan sebagai bahan bakar alternatif dan ramah lingkungan dalam kehidupan sehari-hari [13].

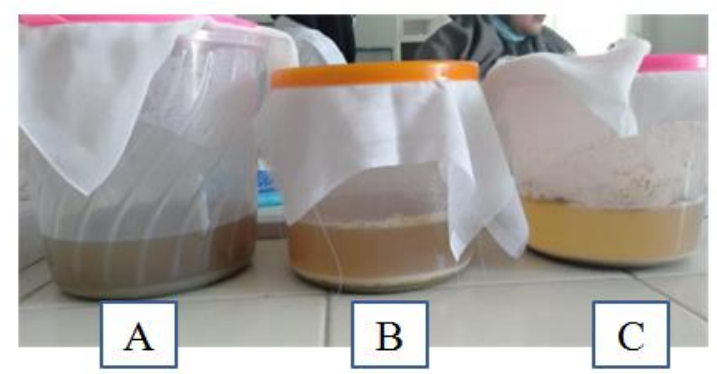

Gambar 1. Proses Fermentasi. (A) Fermentasi dengan konsentrasi $0,5 \% \mathrm{H}_{2} \mathrm{SO}_{4}$, (B) Fermentasi dengan $1 \%$ $\mathrm{H}_{2} \mathrm{SO}_{4}$, (C) Fermentasi dengan $5 \% \mathrm{H}_{2} \mathrm{SO}_{4}$
Berdasarkan penelitian Miskah dkk, yang menyebutkan bahwa proses fermentasi akan meningkatkan glukosa yang dihasilkan oleh hidrolisis sehingga meningkatkan produksi etanol. Faktorfaktor yang mempengaruhi proses fermentasi antara lama waktu fermentasi, jenis mikroorganisme, nilai pH, suhu dan jumlah karbohidrat [7]. Hasil dari proses fermentasi dapat dilihat pada Gambar 1.

Gambar 1 menunjukan hasil uji fermentasi konsentrasi asam sulfat $\left(\mathrm{H}_{2} \mathrm{SO}_{4}\right) 0,5 \% ; 1 \%$ dan $5 \%$. Asam sulfat $\left(\mathrm{H}_{2} \mathrm{SO}_{4}\right)$ yang merupakan katalis asam kuat digunakan untuk mempercepat laju reaksi dalam produksi bioetanol. Semakin tinggi konsentrasi asam sulfat maka laju reaksi hidrolisis juga akan semakin cepat. Hal ini menyebabkan proses perombakan polisakarida menjadi glukosa akan semakin cepat dan banyak terbentuk. Perbedaannya dapat dilihat dari perbedaan warna pada masing-masing konsentrasi. Konsentrasi asam yang tinggi lebih dari 3\%, menyebabkan pengendapan kapur pada limbah dalam jumlah besar, sehingga warna berubah dari hijau keruh menjadi kuning. Sedangkan konsentrasi $\mathrm{H}_{2} \mathrm{SO}_{4}$ pada limbah kapur yang dihasilkan kurang dari $3 \%$, dan warnanya berubah dari hijau menjadi hijau keruh dan hijau kecoklatan [7].

Proses pemisahan etanol dengan campurannya dengan cara distilasi, sehingga diperoleh bioetanol murni. Proses distilasi menggunakan suhu $78^{\circ} \mathrm{C}$ yang merupakan titik didih dari etanol. Etanol akan menguap terlebih dahulu dan ditampung ditempat penampungan. Keunggulan dari teknologi distilasi ini adalah mencapai keseimbangan untuk memiliki tingkat konversi yang tinggi, meminimalkan biaya produksi dan waktu distilasi, serta kemurnian yang tinggi [14]. Tabel 1 mencantumkan hasil uji bioetanol, dimana konsentrasi $\mathrm{H}_{2} \mathrm{SO}_{4}$ dibandingkan dengan parameter terbentuknya bioetanol.

Tabel 1. Perbandingan antara Variasi Konsentrasi $\mathrm{H}_{2} \mathrm{SO}_{4}$ dengan Uji Bioetanol

\begin{tabular}{|c|c|c|c|c|}
\hline \multirow{2}{*}{ Konsentrasi H2SO4 } & \multirow{2}{*}{$\begin{array}{c}\text { \% Yield } \\
\text { Bioetanol }\end{array}$} & $\begin{array}{c}\text { Massa jenis } \\
(\mathbf{g} / \mathbf{m L}) \\
\text { Bioetanol }\end{array}$ & \multicolumn{2}{|c|}{ Uji Warna Bioetanol } \\
\cline { 4 - 5 } & 22 & 0,9621 & Tidak Berwarna & Hijau kebiruan \\
\hline $0,5 \%$ & 25 & 0,9151 & Tidak Berwarna & Hijau kebiruan \\
\hline $1 \%$ & 15 & 0,6548 & Tidak Berwarna & Jingga \\
\hline
\end{tabular}

Berdasarkan Tabel 1 terlihat bahwa konsentrasi $\mathrm{H}_{2} \mathrm{SO}_{4}$ dalam proses hidrolisis akan mempengaruhi persen yield dan densitas etanol yang dihasilkan. Miskah menjelaskan dalam studinya bahwa konsentrasi $\mathrm{H}_{2} \mathrm{SO}_{4}$ mempengaruhi etanol yang dihasilkan [7]. Pada proses hidrolisis yang melibatkan katalis asam terjadi perombakan dari polisakarida menjadi glukosa. Glukosa akan berubah menjadi furfural dan hidroksimetil furfural, yang akhirnya membentuk asam formiat [15]. Furfural $\left(\mathrm{C}_{5} \mathrm{H}_{4} \mathrm{O}_{2}\right)$ biasa disebut 2-furfural, furan aldehyde, furan aldehyde, 2-furandicarbaldehyde, merupakan cairan yang mengandung gula pentosa yang dihasilkan dari limbah biomassa pertanian.

Persen yield bioetanol yang dihasilkan paling banyak pada konsentrasi $\mathrm{H}_{2} \mathrm{SO}_{4} 1 \%$ diikuti $0,5 \%$ dan 
5\%. Oleh karena itu, dapat dikatakan bahwa konsentrasi $\mathrm{H}_{2} \mathrm{SO}_{4}$ yang paling bagus untuk mendapatkan bioetanol adalah $1 \%$. Pada konsentrasi $\mathrm{H}_{2} \mathrm{SO}_{4} 0,5 \%$ laju perombakan selulosa berjalan lambat karena konsentrasinya terlalu rendah sehingga produk yang dihasilkan sedikit. Sedangkan pada konsentrasi $5 \%$, laju reaksi akan berjalan terlalu cepat namun proses penguraian belum sempurna sehingga produk etanol yang dihasilkan juga sedikit [16].

Berdasarkan pengujian densitas etanol standar yang dilakukan dengan cara yang sama dengan pengujian bioetanol yang dihasilkan diperoleh densitas etanol standar sebesar 0,9042 g/mL. Etanol standar yang digunakan adalah etanol murni $96 \%$.

$$
\begin{gathered}
3 \mathrm{R}-\mathrm{CH}_{2} \mathrm{OH}+2 \mathrm{~K}^{+}+\mathrm{Cr}_{2} \mathrm{O}_{7}^{2-}+4 \mathrm{H}_{2} \mathrm{SO}_{4} \longrightarrow 3 \\
\text { Kuning }
\end{gathered}
$$

Perbedaan warna bioetanol yang diperoleh dapat dilihat pada Gambar 2.

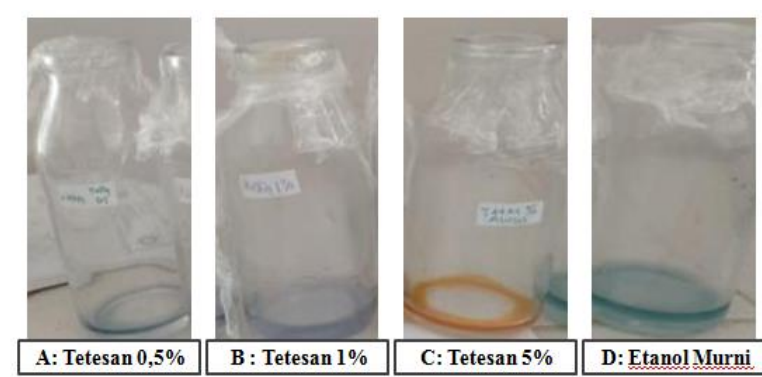

Gambar 2. Etanol yang dihasilkan dari penambahan konsentrasi $\mathrm{H}_{2} \mathrm{SO}_{4}$ A. 0,5\%, B. 1\%, C. $5 \%$, D. Etanol standar

Etanol memiligi gugus fungsi hidroksil. Gugus fungsi hidroksil ini akan bereaksi dengan $\mathrm{K}_{2} \mathrm{Cr}_{2} \mathrm{O}_{7}$ menghasilkan gugus aldehid dan terjadi perubahan warna. Penelitian Jamaliah dkk menyebutkan bahwa reaksi tersebut terjadi karena gugus - $\mathrm{OH}$ pada alkohol primer etanol yang teroksidasi dan digabungkan dengan pereaksi kalium dikromat dalam ikatan rantai karbon membentuk aldehida. Reaksi asam dikromat mengoksidasi alkohol primer menghasilkan aldehida, dan reaksi asam dikromat menjadi asam karena penambahan $\mathrm{H}_{2} \mathrm{SO}_{4}$. Oksidasi lanjutan aldehida akan menghasilkan asam karboksilat. Apabila yang teroksidasi alkohol sekunder, akan diperoleh keton. Pada alkohol tersier terjadi perubahan warna etanol dari jingga (ion $\mathrm{Cr}_{2} \mathrm{O}_{7}^{2-}$ ) dikromat berubah menjadi biru-hijau (ion $\mathrm{Cr}_{3}{ }^{+}$) [5]. Konsentrasi $\mathrm{H}_{2} \mathrm{SO}_{4}$ yang semakin tinggi selama proses fermentasi dan lamanya proses fermentasi mempengaruhi tingkat perubahan warna [18].

Indikator terbentuknya etanol adalah terjadinya perubahan warna menjadi hijau kebiruan. Dalam penelitian ini etanol yang diperoleh dari konsentrasi $\mathrm{H}_{2} \mathrm{SO}_{4} \quad 0,5 \%$ dan $1 \%$ mengalami perubahan warna
Sehingga dapat diketahui bahwa pada konsentrasi $\mathrm{H}_{2} \mathrm{SO}_{4} 0,5 \%$ dan $1 \%$ yang memiliki densitas masingmasing $0,9621 \mathrm{~g} / \mathrm{mL}$ dan $0,9151 \mathrm{~g} / \mathrm{mL}$ memiliki densitas yang tidak jauh berbeda dengan etanol standar. Sedangan etanol yang diperoleh dari konsentrasi $\mathrm{H}_{2} \mathrm{SO}_{4} 5 \%$ menghasilkan densitas yang lebih kecil dari etanol standar. Perbedaan ini disebabkan laju reaksi pembentukan etanol terlalu cepat pada konsentrasi katalis yang lebih tinggi sehingga tidak terjadi keseimbangan atara laju dan produk yang dihasilkan [17]. Pengujian etanol dengan perubahan warna karena terjadi persamaan reaksi berikut:

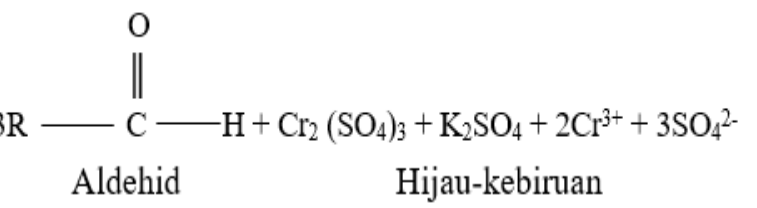

menjadi hijau kebiruan, hal ini sama dengan perubahan warna pada etanol standar. Oleh karena itu dapat dikatakan bahwa etanol sudah terbentuk pada konsentrasi $\mathrm{H}_{2} \mathrm{SO}_{4} 0,5 \%$ dan $1 \%$. Sedangkan pada konsentrasi $\mathrm{H}_{2} \mathrm{SO}_{4} 5 \%$ warna larutan berubah menjadi jingga sama dengan warna larutan $\mathrm{K}_{2} \mathrm{Cr}_{2} \mathrm{O}_{7}$, hal ini mengindikasikan tidak terbentuk etanol. Semakin tinggai konsentrasi katalisator yang digunakan dalam pembuatan bioetanol, maka reaksi hidrolisis akan terjadi semakin cepat. Namun, konsentrasi asam yang tinggi pada proses hidrolisis dapat menyebabkan glukosa dan selulosa lain akan terdegradasi menjadi senyawa hidroksi metil furfural (HMF) dan furfural serta membentuk asam formiat, sehingga etanol yang terbentuk sedikit [16].

\section{Kesimpulan}

Bioetanol yang diperoleh dari limbah organik yang berasal dari kulit buah dan sayur dengan variasi konsentrasi katalis menunjukkan bahwa pada penambahan katalis $\mathrm{H}_{2} \mathrm{SO}_{4}$ dengan konsentrasi $0,5 \%$ dan $1 \%$ diperoleh etanol dengan spesifikasi yang mirip dengan etanol standar, hal ini dapat dilihat berdasarkan perhitungan densitas dan uji perubahan warna. Hasil etanol yang diperoleh atau \% yield terbanyak diperoleh dari konsentrasi $\mathrm{H}_{2} \mathrm{SO}_{4} 1 \%$.

\section{Daftar Pustaka}

[1] Anonim, Dokumen Rencana Strategis Sekretariat Jenderal Kementerian Energi dan Sumber Daya Mineral Tahun 2015-2019, KESDM, Jakarta Pusat, 2019, p.1-106.

[2] A. D. Kurniawan, Semin, and T. Suprajitno, "Analisa penggunaan bahan bakar bioethanol dari batang padi sebagai campuran pada bensin," J. Tek. ITS, vol. 3, no. 1, 2014.

[3] D. Seftian, F. Antonius, and M. Faizal, "Pembuatan etanol dari kulit pisang menggunakan metode hidrolisis enzimatik dan fermentasi," J. Tek. Kim., vol. 18, no. 1, 
pp. 10-16, 2012.

[4] W. Wusnah, S. Bahri, and D. Hartono, "Proses pembuatan bioetanol dari kulit pisang kepok (Musa acuminata B.C) secara fermentasi," J. Teknol. Kim. Unimal, vol. 8, no. 1, p. $48,2019$.

[5] M. Jamaliah, "Sintesis etanol melalui reaksi hidrogenasi heksil asetat dengan menggunakan berbagai katalis", Skripsi, UIN Syarif Hidayatullah, Jakarta, 2011.

[6] D. E. Hasianna Purba, I. E. Suprihatin, and A. A. I. A. M. Laksmiwati, "Pembuatan Bioetanol dari kupasan kentang (Solanum tuberosum L.) dengan Proses fermentasi," J. Kim., vol. 10, no. 1, pp. 155-160, 2016.

[7] S. Miskah, A. Anugrah, and Gunadi, "Pemanfaatan Kulit telur sebagai katalis biodiesel dari campuran minyak jelantah dan minyak kelapa sawit," J. Tek. Kim., vol. 22, no. 2, pp. 54-61, 2016.

[8] F. Apriliani, Asteria dan Agustinus, "Pembuatan Etanol dari kulit pisang secara fermentasi," J. Teknol. Kim. dan Ind., vol. 2, no. 2, pp. 177-180, 2013.

[9] F. Hanum, N. Pohan, M. Rambe, R. Primadony, and M. Ulyana, "Pengaruh massa ragi dan waktu fermentasi terhadap bioetanol dari biji durian," J. Tek. Kim. USU, vol. 2, no. 4, pp. 49-54, 2013.

[10] D. Pinata, "Uji kualitatif etanol yang di produksi secara enzimatis menggunakan Zymomonas mobilis permeabel", Skripsi, Institut Teknologi Sepuluh November, Surabaya, 2011.

[11] L. O. A. D. Asidu, M. Hasbi, and P. Aksar, "Pemanfaatan minyak oli bekas sebagai bahan bakar alternatif dengan pencampuran minyak pirolisis," J. Mhs. Tek. Mesin, vol. 2, no. 2, pp. 1-7, 2017.

[12] F. Asip, B. Febrianti, and S. Gibreallah, "Bioetanol dengan bahan baku sabut kelapa," J. Tek. Kim., vol. 23, no. 3, pp. 157-165, 2017.

[13] D. Anisah, Herliati, and A. Widyaningrum, "Pemanfaatan Sampah sayuran sebagai bahan baku pembuatan bioetanol," Konversi, vol. 3, no. 1, pp. 13-18, 2014.

[14] K. Kusmiyati, "Reaksi Katalitis esterifikasi asam oleat dan metanol menjadi biodiesel dengan metode distilasi reaktif," Reaktor, vol. 12, no. 2, p. 78, 2008.

[15] A. Sukowati, Sutikno, and S. Rizal, "Produksi Bioetanol dari kulit pisang melalui hidrolisis asam sulfat," J. Teknol. dan Ind. Has. Pertan. Vol., vol. 19, no. 3, pp. 274-288, 2014.

[16] R. Muin, D. Lestari, and T. W. Sari, "Pengaruh konsentrasi asam sulfat dan waktu fermentasi terhadap kadar bioetanol yang dihasilkan dari biji alpukat," J. Tek. Kim., vol. 20, no. 4, pp. 1-7, 2015.

[17] A. Rachmayanti, R. M. Sari, and A. F.
Ilhamdy, "Proses sakarifikasi dan fermentasi terpisah pada produksi bioetanol dari bahan baku rumput laut Sargassum sp.," Marinade, vol. 2, no. 1, pp. 19-28, 2019.

[18] Y. V. Simatupang, I. M. Mahaputra Wijaya, and N. S. Antara, "Isolasi dan karakterisasi bakteri potensial penghasil etanol dari industri arak Bali di Karangasem-Bali," J. Rekayasa Dan Manaj. Agroindustri, vol. 7, no. 1, p. 58, 2019. 